\title{
Effect of long-term, year-long grazing at moderate and heavy rates of stocking on diet selection and forage intake dynamics
}

\author{
WILLIAM E. PINCHAK, STEPHEN K. CANON, RODNEY K. HEITSCHMIDT, AND STEVEN L. DOWHER
}

\begin{abstract}
A 2-year experiment was conducted to determine the effect of 27 years of continuous grazing at moderate $(7 \mathrm{ha} / \mathrm{cow} / \mathrm{yr})(\mathrm{MC})$ and heavy ( $5 \mathrm{ha} / \mathrm{cow} / \mathrm{yr})(\mathrm{HC})$ rates of stocking on seasonal diet selection and forage intake dynamics. Nine trials were conducted to determine differences between treatments in botanical composition and quality of diets and forage intake. Proportion of Texas wintergrass (Stipa leucothrica Trin. and Rupr.) in diets was greater $(P<.05)$ in the MC than HC treatment whereas amounts of warmseason short- and midgrasses were less. Differences between treatments in botanical composition of diets were related to differences in seasonal availability and live:dead tissue ratios of forages. However, such differences did not generally affect diet quality. Supplementation of HC cattle with $20 \%$ CP breeder cube either replaced forage organic matter intake (January 1986) or substituted for insufficient forage availability (February 1987). Supplementation never stimulated forage intake. Forage organic matter intake was restricted at forage standing crops below $700 \mathrm{~kg} / \mathrm{ha}$.
\end{abstract}

Key Words: forage intake, digestibility, protein, range condition, supplemental feeding

Livestock production from forage based systems is the integrated product of complex interactions among (1) quantity and quality of forage produced, (2) quantity and quality of forage consumed, and (3) the efficiency with which consumed nutrients are converted into animal biomass. The primary factor affecting these relationships is stocking rate (Hart 1978). These relationships become increasingly complex in multi-species rangeland environments, because rate of stocking often alters species composition and biomass production (Jameson 1963, Ellison 1960) as a result of the discretionary effects of varying levels of stocking rate on the frequency and severity of defoliation of individual plants (Gammon and Roberts 1978, Briske and Stuth 1982).

The effects of long-term grazing practices on seasonal profiles of diet selection and nutrient intake are not well known (Cook et al. 1962, Cook and Harris 1968). The objective of this study was to quantify the effects of 27 years of yearlong continuous grazing at 2 stocking rates on seasonal dynamics of the quantity and quality of forage consumed.

\section{Methods}

\section{Study Site}

Research was conducted at the Texas Experimental Ranch located $\left(99^{\circ} 14^{\prime} \mathrm{W}, 33^{\circ} 20^{\prime} \mathrm{N}\right)$ on the eastern edge of the Rolling Plains. Climate is continental and semiarid. Precipitation is vari-

\footnotetext{
Authors are assistant professor, former research associate, professor, and research associate, Texas Agr. Exp. Sta., Box 1658, Vernon 76384.

Appreciation is expressed to the Swen R. Swenson Cattle Co. for providing land, livestock and facilities for this study and the Texas Experimental Ranch Committee for providing financial assistance.

The authors wish to acknowledge contributions of J.C. Cornett, L.J. Hunt, K.J. Young and M.S. Stone in process of collecting field data, completing laboratory analyses, and in manuscript preparation.

This report is published with the approval of the Director, Texas Agricultural Experiment Station as TA 25101 .

Manuscript accepted 12 December 1989.
}

able and bimodally distributed with peak rainfall occurring in May $(9.2 \mathrm{~cm})$ and September $(10.6 \mathrm{~cm})$ (Fig. 1). Average annual precipitation (1960-1987) is $68 \mathrm{~cm}$. Average maximum daily temperatures range from a high of $36^{\circ} \mathrm{C}$ in July to a low of $11^{\circ} \mathrm{C}$ in January.

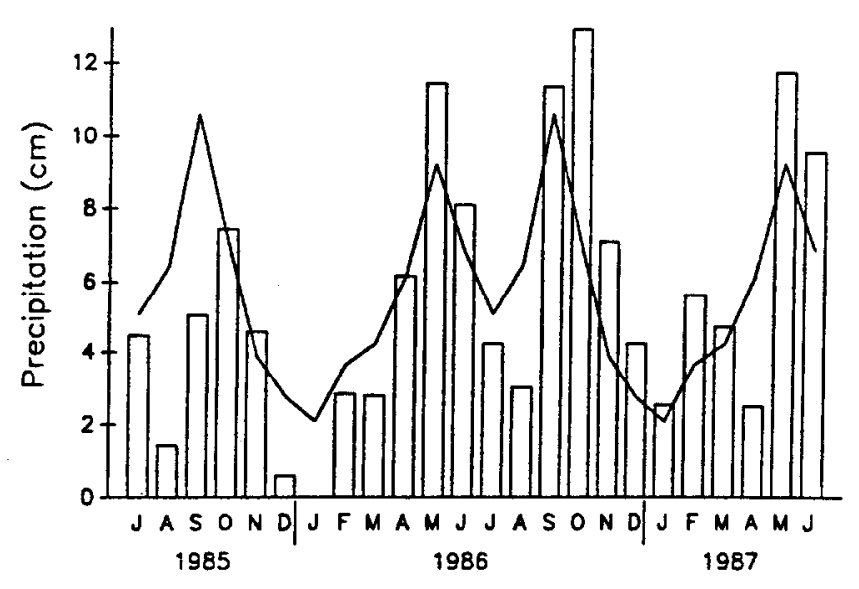

Fig. 1. Monthly precipitation in cm (bars) over the study period July 1985 to June 1987 relative to long-term 28-year average (line) at the Texas Experimental Ranch.

Topography is rolling and ranges from broad valleys and gentle slopes that lead to nearly level uplands to narrow secondary valleys with moderate to steep slopes. Elevation ranges from 408 to $463 \mathrm{~m}$. Dominant range sites are Clay Loam, Clayey Upland, Clay Slopes, Rocky Hills and Loamy Bottomland.

Vegetation is a mixed-grass complex within a light to moderate stand of honey mesquite [(Prosopis glandulosa (Torr.) var. glandulosa)]. Dominant midgrasses are Texas wintergrass (Stipa leucotrica Trin. \& Rupr.), a cool-season perennial; sideoats grama [(Bouteloua curtipendula (Michx.) Torr.], a warm-season perennial; and Japanese brome (Bromus japonicus Thunb.), a coolseason annual. Dominant shortgrasses are buffalograss [( Buchloe dactyloides (Nutt.) Engelm.] and common curlymesquite [(Hilaria berlangeri (Steud.) Nash], both warm-season perennials. The dominant forb is annual broomweed (Xanthocephalum spp.). For a more complete description of the climate, soils, and vegetation of the ranch, see Heitschmidt et al. (1985).

\section{Treatments}

Grazing treatments were yearlong continuous stocked with mature F1 Angus/Hereford cows at heavy (HC) and moderate (MC) rates. The 2 treatments were initiated in 1960 in 4 replicated pastures that ranged in size from 218 to 266 ha.

Prior to 1960 , the 4 pastures were part of a single 2,900 ha pasture. At the time of subdivision, all pastures were deemed to be in similar range condition (W.J. Waldrip, personal communication). Subsequent vegetation analyses support this contention 
(Kothmann et al. 1978, Heitschmidt et al. 1985). Average rates of stocking from 1960 through 1984 were about 5 and $7 \mathrm{ha} / \mathrm{cow} / \mathrm{yr}$, respectively. During this 2-year study (1985-1987), rates of stocking were 5.0 and $6.4 \mathrm{ha} / \mathrm{cow} / \mathrm{yr}$. Detailed descriptions of pasture and range site, plant composition, and standing crop dynamics are presented by Heitschmidt et al. (1989).

\section{Diet and Intake Sampling}

During each of 9 trials (July 1985 through June 1987), 8 to 12 esophageally fistulated Angus-Hereford $X$ Jersey steers (268-830 $\mathrm{kg}$ ) were randomly assigned to 1 replicate pasture of each treatment after stratifing by weight. After a 1-week presampling adaptation period, diet samples were collected the following week at daylight on Monday, Wednesday, and Friday to coincide with early morning grazing. On Saturday, the 2 groups of steers were crossed-over between treatments and moved to the second set of replicate pastures where the sampling scheme was repeated. Steers were allowed to graze for $\mathbf{3 0}$ to $\mathbf{4 5}$ minutes or until screen-bottom collection bags were full. Individual samples were thoroughly mixed, sealed in labeled plastic bags, and frozen within 30 minutes of collection. In an attempt to estimate pasture-level diet selection and quality patterns, samples were collected from a different location each day in a pasture.

Ytterbium ( $\mathrm{Yb}$ ) chloride was used as the inert marker. Marker capsules were prepared by absorbing ytterbium chloride onto clean, previously sieved ( 10 Mesh) dried softwood sawdust at a rate of $40 \% \mathrm{Yb}$ to $60 \%$ sawdust $(w / w)$ following the technique of Teeter et al. (1984), with 1 modification: the post-drying rinse step was omitted. Boluses consisted of $10 \mathrm{~g}$ of marker/carrier. Twenty boluses from each batch were selected at random to determine actual Yb content. Marker capsules were orally administered daily at daylight beginning on day 1 of the pretrial adaptation period. Rectal fecal grab samples were taken at the same time as marker administration. Fecal samples were individually bagged and frozen within an hour of collection.

Steers were weighed on days 1,14 , and 21 of each trial. Cattle in the HC treatment are normally fed a $20 \%$ crude protein (CP) winter supplement from January 1 to March 31 at a rate of 0.68 to $1.36 \mathrm{~kg} /$ animal/day. During the January 1986 trial, steers in HC pastures were individually fed $0.68 \mathrm{~kg}$ of supplement/day when feces were sampled. During the February 1987 trial, steers in the HC treatment were fed in the same manner but at a rate of 1.36 $\mathrm{kg}$ /day. Cattle under MC were not supplemented during any trial.

\section{Laboratory Analyses}

Botanical composition of the diet was estimated utilizing macrohistological techniques as described by Angell et al. (1986). Subsamples (approx. $30 \mathrm{~g}$ dry weight) of individual diet samples were composited by date within pasture. After thorough mixing, composited samples were evenly distributed on a tray and 100 fragments were selected at random and classified under a binocular microscope at a magnification of $100 \times$ into 1 of 6 species or species groups (species): sideoats grama, Texas wintergrass, shortgrasses, other warm-season grasses, annual grasses, and forbs.

Approximately $20 \%$ of all diet and fecal samples collected in each trial were subsampled and either oven dried at $50^{\circ} \mathrm{C}$ or lypholized to a constant weight (72 to $120 \mathrm{hr}$ ). The remaining samples were oven dried and subsequently adjusted to a lypholized basis by correction factors for each constituent analyzed.

After drying, extrusa and fecal samples were ground to pass a $1-\mathrm{mm}$ screen in a Wiley mill. Extrusa samples were analyzed for dry matter (DM), organic matter (OM), and ash by AOAC (1980) procedures. Crude protein (CP) was calculated by multiplying Kjeldahl nitrogen by 6.25 (AOAC 1980). Acid-detergent fiber (ADF) was analyzed by procedures of Van Soest and Wine (1967). In vitro organic matter digestibility (IVOMD) was estimated utiliz-

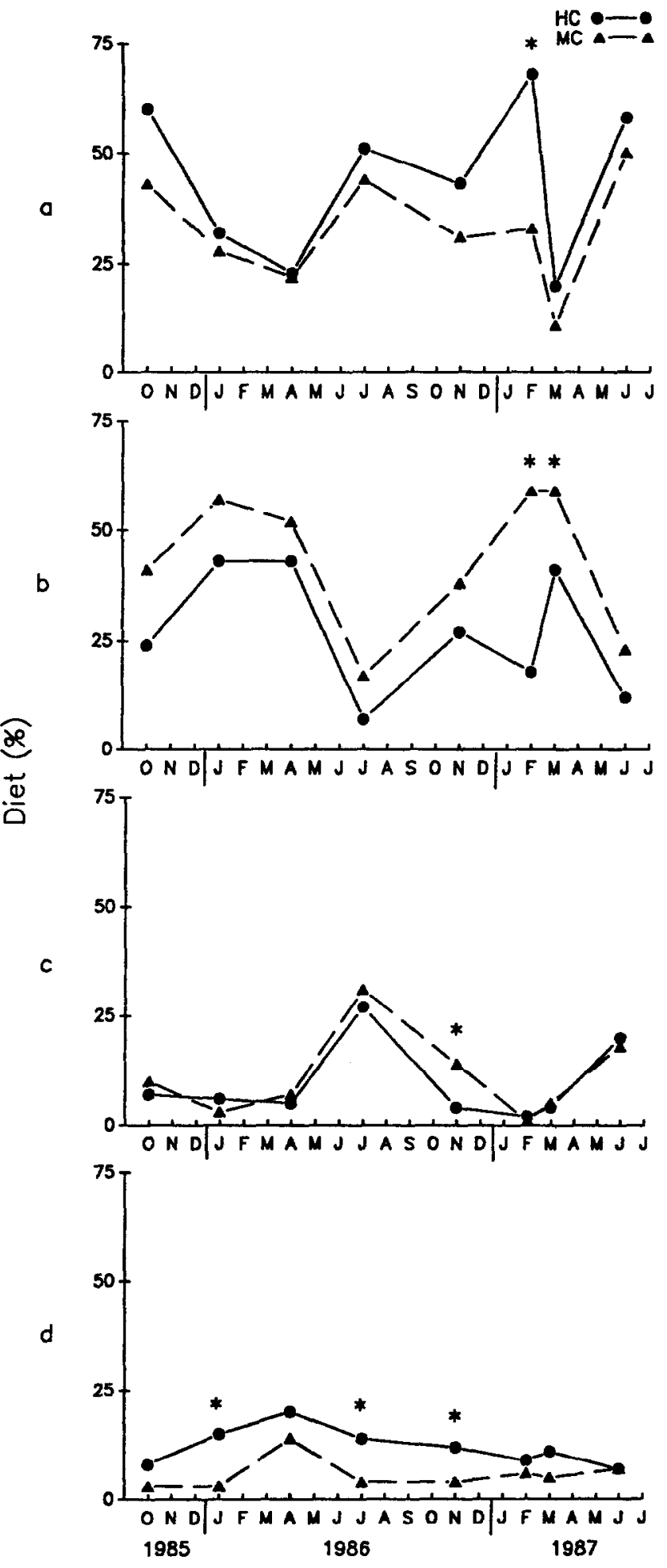

Fig. 2. Species composition (\%) of diets in heavy continuous (HC) and moderate continuous (MC) treatments on 9 dates. (a) warm-season grasses; (b) Texas wintergrass; (c) sldecats grama and (d) shortgrasses. Asterisk $(*)$ above a date denotes a significant $(P<0.05)$ treatment effect.

ing a modified 2-stage incubation technique. The first stage was a standard 48-hr incubation in rumen fluid (Tilley and Terry 1963), collected from a single steer maintained on bermudagrass hay and a complete mineral supplement. A neutral solution extraction was substituted for acid-pepsin incubation in the second stage as described by Van Soest et al. (1966). In vitro values were adjusted by 
correction factors for in vivo standards in each batch. All results are presented on an $\mathrm{OM}$ basis.

Fecal $\mathrm{Yb}$ concentrations were estimated by dry ashing a $1 \mathrm{~g}$ sample for $12 \mathrm{hr}$ at $510^{\circ} \mathrm{C}$ prior to overnight digestion in $10 \mathrm{ml}$ of $25 \%(\mathrm{v} / \mathrm{v})$ solution of $3.3 \mathrm{HNO}_{3}: 1.7 \mathrm{HCl}$. A 2-ml aliquot was diluted to $8 \mathrm{ml}$ with $25 \%(\mathrm{v} / \mathrm{v}) \mathrm{KCl}$ solution to suppress background ionic interference, and subjected to atomic absorption spectroscopy analyses (nitrous oxide/air-acetylene flame, Varian Model 1475). Ytterbium concentrations in the marker boluses were analyzed in the same manner as fecal samples.

\section{Data Summarization and Statistical Analyses}

Fecal output (FO) was estimated by dividing fecal Yb concentration $(\mathrm{g} / \mathrm{g}$ ) into dose concentration (g) assuming complete $\mathrm{Yb}$ recovery in the feces. Forage fecal output (FFO) was estimated by subtracting in vitro estimated undigested residue $(20 \%)$ of the supplement from total fecal organic matter output. Organic matter (OMI) and forage organic matter intake (FOMI) were calculated utilizing FO or FFO, respectively. Forage organic matter intake and $\mathrm{OMI}$ were calculated on an $\mathrm{OM}$ basis and are presented as a percentage of body weight (BWT).

All data were summarized by pasture (replication) within trial (date) and statistically analyzed using repeated measures analysis of variance (AOV) procedures (Gurevitch and Chester 1986). Treatment effects on botanical composition were determined using pasture within treatment as the error term. Species and the treatment $X$ species interaction were tested by the species $X$ pasture within treatment interaction. Trial (date) and treatment $\times$ trial were tested by trial $X$ pastures within treatment interaction. The species $X$ trial and treatment $X$ species $X$ trial were tested by the species $X$ pastures within trial interaction. A protected StudentNeuman-Keuls (SNK) was employed for mean separation.

Nutrient quality of diets and intake data were analyzed by repeated measures, split-plot AOV. Treatment effects were determined using pasture within treatment as the error term. Trial and the treatment $X$ trial interaction were tested by residual error. Means separation was with SNK. Unless otherwise stated, significance is at a $P<0.05$.
Table 1. Treatment means for botanical composition of diets, diet quality and organic matter intake parameters averaged across 9 sample dates.

\begin{tabular}{|c|c|c|}
\hline & Treatment & \\
\hline Parameter & $\begin{array}{l}\text { Heavy } \\
\text { continuous } \\
\text { (HC) }\end{array}$ & $\begin{array}{l}\text { Moderate } \\
\text { continuous } \\
\text { (MC) }\end{array}$ \\
\hline $\begin{array}{l}\text { Botanical Composition }(\%)^{1} \\
\text { Texas wintergrass }{ }^{2} \\
\text { Sideoats grama }{ }^{2} \\
\text { Shortgrasses }{ }^{2} \\
\text { Other warm-season grasses } 2 \\
\text { Annual grasses } \\
\text { Forbs }\end{array}$ & $\begin{array}{r}28^{\mathrm{b3}} \\
8^{\mathrm{cd}} \\
12^{\mathrm{c}} \\
44^{\mathrm{a}} \\
6^{\mathrm{d}} \\
3^{\mathrm{d}}\end{array}$ & $\begin{array}{r}44^{c} \\
11^{d} \\
6^{d} \\
32^{b} \\
4^{d} \\
2^{d}\end{array}$ \\
\hline $\begin{array}{l}\text { Diet Quality }(\%) \\
\text { In vitro organic matter digestibility } \\
\text { (IVOMD) } \\
\text { Acid detergent fiber (ADF) } \\
\text { Organic matter (OM) }\end{array}$ & $\begin{array}{l}60 \\
45 \\
84\end{array}$ & $\begin{array}{l}59 \\
46 \\
85\end{array}$ \\
\hline $\begin{array}{l}\text { Organic Matter Intake ( } \% \text { of body weight) } \\
\text { Forage (FOMI) } \\
\text { Total (OMI) }\end{array}$ & $\begin{array}{l}1.87 \\
1.93\end{array}$ & $\begin{array}{l}1.89 \\
1.89\end{array}$ \\
\hline
\end{tabular}

ISignificant $(P<0.05)$ treatment by date by species interaction.

${ }_{2}^{2}$ ignificant $(P<0.05)$ treatment by date by interaction. Means not having a common superscript differ at $P<.05$.

\section{Results}

\section{Diet Composition}

Although the proportions of Texas wintergrass, sideoats grama, and warm-season short- and midgrasses varied as a complex function of treatment and trial (Fig. 2), relative differences were similar when averaged across dates (Table 1) or trials (Table 2). Texas wintergrass was the major species consumed in the $\mathrm{MC}$ treatment whereas the HC diets were dominated by shortgrasses and other warm-season grasses. There was no difference between treatments in the proportion of sideoats grama, annual grasses and forbs in diets when averaged across trials.

Table 2. Botanical composition of diets, diet quality and organic matter intake parameters averaged across 2 treatments for each trial date.

\begin{tabular}{|c|c|c|c|c|c|c|c|c|c|}
\hline \multirow[b]{2}{*}{ Parameter } & \multicolumn{9}{|c|}{ Date } \\
\hline & $\begin{array}{l}\text { July } \\
1985\end{array}$ & $\begin{array}{c}\text { October } \\
1985\end{array}$ & $\begin{array}{l}\text { January } \\
1986\end{array}$ & $\begin{array}{l}\text { April } \\
1986\end{array}$ & $\begin{array}{l}\text { July } \\
1986\end{array}$ & $\begin{array}{l}\text { November } \\
1986\end{array}$ & $\begin{array}{c}\text { February } \\
1987\end{array}$ & $\begin{array}{c}\text { March } \\
1987\end{array}$ & $\begin{array}{l}\text { June } \\
1987\end{array}$ \\
\hline $\begin{array}{l}\text { Botanical Composition }(\%)^{1} \\
\text { Texas wintergrass }{ }^{2} \\
\text { Sideoats grama }^{2} \\
\text { Shortgrasses } \\
\text { Other warm-season grasses }{ }^{2} \\
\text { Annual grasses } \\
\text { Forbs }\end{array}$ & $\begin{array}{l}- \\
\overline{-} \\
= \\
-\end{array}$ & $\begin{array}{c}32 \mathrm{ab}^{3} \\
9 \mathrm{c} \\
5 \mathrm{~b} \\
51 \mathrm{ab} \\
3 \mathrm{~b} \\
\mathrm{Ib}\end{array}$ & $\begin{array}{c}50 \mathrm{a} \\
5 \mathrm{c} \\
10 \mathrm{ab} \\
30 \mathrm{~cd} \\
4 \mathrm{~b} \\
1 \mathrm{~b}\end{array}$ & $\begin{array}{c}48 \mathrm{a} \\
6 \mathrm{c} \\
17 \mathrm{a} \\
22 \mathrm{de} \\
7 \mathrm{~b} \\
1 \mathrm{~b}\end{array}$ & $\begin{array}{c}13 \mathrm{c} \\
30 \mathrm{a} \\
9 \mathrm{~b} \\
47 \mathrm{ab} \\
2 \mathrm{~b} \\
1 \mathrm{~b}\end{array}$ & $\begin{array}{c}32 \mathrm{ab} \\
9 \mathrm{c} \\
8 \mathrm{~b} \\
37 \mathrm{bc} \\
3 \mathrm{~b} \\
7 \mathrm{a}\end{array}$ & $\begin{array}{c}39 \mathrm{a} \\
1 \mathrm{c} \\
7 \mathrm{~b} \\
51 \mathrm{ab} \\
2 \mathrm{~b} \\
1 \mathrm{~b}\end{array}$ & $\begin{array}{r}50 \mathrm{a} \\
5 \mathrm{c} \\
8 \mathrm{~b} \\
15 \mathrm{e} \\
17 \mathrm{a} \\
5 \mathrm{a}\end{array}$ & $\begin{array}{c}17 b c \\
19 b \\
7 b \\
54 a \\
1 b \\
2 b\end{array}$ \\
\hline $\begin{array}{l}\text { Diet Quality (\%) } \\
\text { In vitro organic matter } \\
\text { digestibility (IVOMD) } \\
\text { Crude protein (CP) } \\
\text { Acid detergent fiber (ADF) } \\
\text { Organic Matter (OM) }\end{array}$ & $\begin{array}{c}58 \mathrm{~b} \\
8.8 \mathrm{de} \\
51 \mathrm{a} \\
86 \mathrm{~cd}\end{array}$ & $\begin{array}{l}55 c \\
8.8 \mathrm{de} \\
49 \mathrm{a} \\
84 \mathrm{bc}\end{array}$ & $\begin{array}{c}54 \mathrm{c} \\
7.0 \mathrm{e} \\
49 \mathrm{a} \\
85 \mathrm{~cd}\end{array}$ & $\begin{array}{r}63 \mathrm{~b} \\
12.1 \mathrm{~b} \\
44 \mathrm{~b} \\
87 \mathrm{~d}\end{array}$ & $\begin{array}{c}59 \mathrm{~b} \\
9.5 \mathrm{~cd} \\
44 \mathrm{~b} \\
86 \mathrm{~cd}\end{array}$ & $\begin{array}{c}57 \mathrm{bc} \\
12.3 \mathrm{~b} \\
40 \mathrm{c} \\
83 \mathrm{~b}\end{array}$ & $\begin{array}{c}59 \mathrm{~b} \\
10.9 \mathrm{bc} \\
44 \mathrm{~b} \\
79 \mathrm{a}\end{array}$ & $\begin{array}{r}65 a \\
19.6 a \\
38 c \\
81 a\end{array}$ & $\begin{array}{r}63 b \\
11.8 b \\
49 a \\
87 d\end{array}$ \\
\hline $\begin{array}{l}\text { Intake (\% BWT) } \\
\text { Organic Matter Intake (OMI) }\end{array}$ & $2.45 \mathrm{a}$ & $1.95 \mathrm{c}$ & $2.21 \mathrm{~b}$ & $2.42 \mathrm{a}$ & $1.83 c$ & $1.96 \mathrm{c}$ & $1.40 \mathrm{e}$ & $1.64 d$ & $1.43 \mathrm{e}$ \\
\hline $\begin{array}{l}\text { Intake }(\% \text { BWT) } \\
\text { Forage Organic Matter Intake } 2 \\
\text { (FOMI) }\end{array}$ & $2.45 \mathrm{a}$ & $1.95 \mathrm{bc}$ & $2.10 \mathrm{~b}$ & $2.42 \mathrm{a}$ & $1.83 c$ & $1.96 \mathrm{bc}$ & $1.22 \mathrm{f}$ & $1.64 d$ & $1.43 \mathrm{e}$ \\
\hline
\end{tabular}

1Significant $(P<0.05)$ treatment by date by species interaction.

2Significant $(P<0.05)$ treatment by date interaction.

${ }^{3}$ Means in a row followed by the same letter are not significantly different at $P<0.05$. 
Table 3. Average graminoid standing crop, percentage crude protein (CP) and in vitro organic matter digestibility (IVOMD) in treatment pastures on 8 dates (from Heitschmidt et al. 1989).

\begin{tabular}{|c|c|c|c|c|c|c|c|c|}
\hline \multirow[b]{2}{*}{ Parameter } & \multicolumn{8}{|c|}{ Date } \\
\hline & $\begin{array}{c}\text { October } \\
1985\end{array}$ & $\begin{array}{c}\text { January } \\
1986\end{array}$ & $\begin{array}{l}\text { April } \\
1986\end{array}$ & $\begin{array}{l}\text { July } \\
1986\end{array}$ & $\begin{array}{c}\text { November } \\
1986\end{array}$ & $\begin{array}{c}\text { February } \\
1987\end{array}$ & $\begin{array}{c}\text { March } \\
1987\end{array}$ & $\begin{array}{l}\text { June } \\
1987\end{array}$ \\
\hline $\begin{array}{l}\text { Standing Crop }(\mathrm{Kg} / \mathrm{ha}) \\
\text { CP (\%) } \\
\text { IVOMD (\%) }\end{array}$ & $\begin{array}{l}1422 \mathrm{abc} \\
6.8 \mathrm{de} \\
43 \mathrm{~b}\end{array}$ & $\begin{array}{c}1154 \mathrm{bc} \\
5.9 \mathrm{e} \\
43 \mathrm{~b}\end{array}$ & $\begin{array}{c}1176 \mathrm{bc} \\
8.8 \mathrm{~b} \\
51 \mathrm{a}\end{array}$ & $\begin{array}{c}1701 \mathrm{a} \\
7.4 \mathrm{~cd} \\
53 \mathrm{a}\end{array}$ & $\begin{array}{c}1567 \mathrm{ab} \\
9.1 \mathrm{~b} \\
45 b\end{array}$ & $\begin{array}{l}960 c \\
8.1 b c \\
45 b\end{array}$ & $\begin{array}{r}1063 \mathrm{c} \\
10.4 \mathrm{a} \\
54 \mathrm{a}\end{array}$ & $\begin{array}{c}1614 a b \\
8.8 b \\
51 a\end{array}$ \\
\hline
\end{tabular}

1Means in a row followed by same letter are not significantly different at $P<0.05$.

Differences in diet composition among dates indicated composition of diets varied as a function of species availability and live:dead tissue ratios. For example, peak amounts of Texas wintergrass were consumed during late fall, winter, and spring (Table 2) when relative availability and live:dead ratios were high (Heitschmidt et al. 1989). Likewise, similar trends were apparent for sideoats grama (July 1986 and June 1987), annual grasses (March 1987), and forbs (November 1986 and March 1987). However, patterned consumption of other warm-season short- and midgrasses was less well defined, particularly under the HC treatment (Fig. 2) where greater forage demand in the heavily stocked treatment tended to reduce the amounts of these species available for consumption at critical times and where there was a greater abundance of the shortgrass species (Heitschmidt et al. 1989). As a result the cattle in the HC treatment were forced to consume greater amounts of warm-season grasses than the cattle in the $\mathrm{MC}$ treatment.

\section{Diet Quality}

Although differences in the botanical composition of diets did occur between the HC and MC treatments, these differences did not significantly alter $\mathrm{OM}, \mathrm{CP}$, IVOMD, or ADF content of diets (Table 1). Although CP under HC was significantly greater than

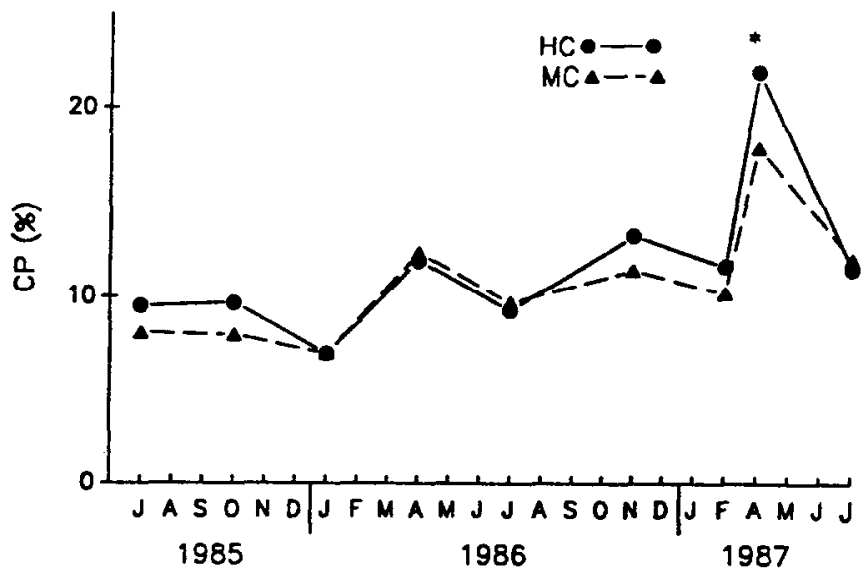

Fig. 3. Seasonal dynamies of dietary crude protein (CP) under long-term heavy ( $\bullet$ ) and moderate $(\Delta)$ continuous grazing (HC and MC, respectively) during 9 trials from July 1985 to June 1987.

MC only in March 1987 (Fig. 3), CP content of HC diets tended to $(P<0.12)$ to be greater than under MC throughout the study period. Trial date significantly affected the content of all constituents measured (Table 2) and closely followed seasonal patterns in forage quality (Table 3). There was also a pronounced year effect on absolute CP content during a season. For example, concentration of CP in the January 1986 diets was $7.0 \%$ vs $10.9 \%$ in the February 1987 diets, a $52 \%$ increase. This increase was largely the result of more abundant precipitation (Fig. 1) in January and February 1987, which enhanced forage growth and subsequent quality (Table 3). Extraordinarly high (18 to $22 \% \mathrm{CP}$ ) dietary $\mathrm{CP}$ concentrations were encountered during the March 1987 trial (Fig. 3). As noted earlier, during this trial over $80 \%$ of the diet in both treatments was comprised of cool-season grasses and forbs (Table 2).

\section{Intake}

Neither OMI nor FOMI were affected by grazing treatment (Table 1 ), but both were affected $(P<.05)$ by trial date (Table 2$)$, and in the case of FOMI, by the treatment $X$ trial interaction (Fig. 4). No discernible trends were apparent that clearly elucidated the
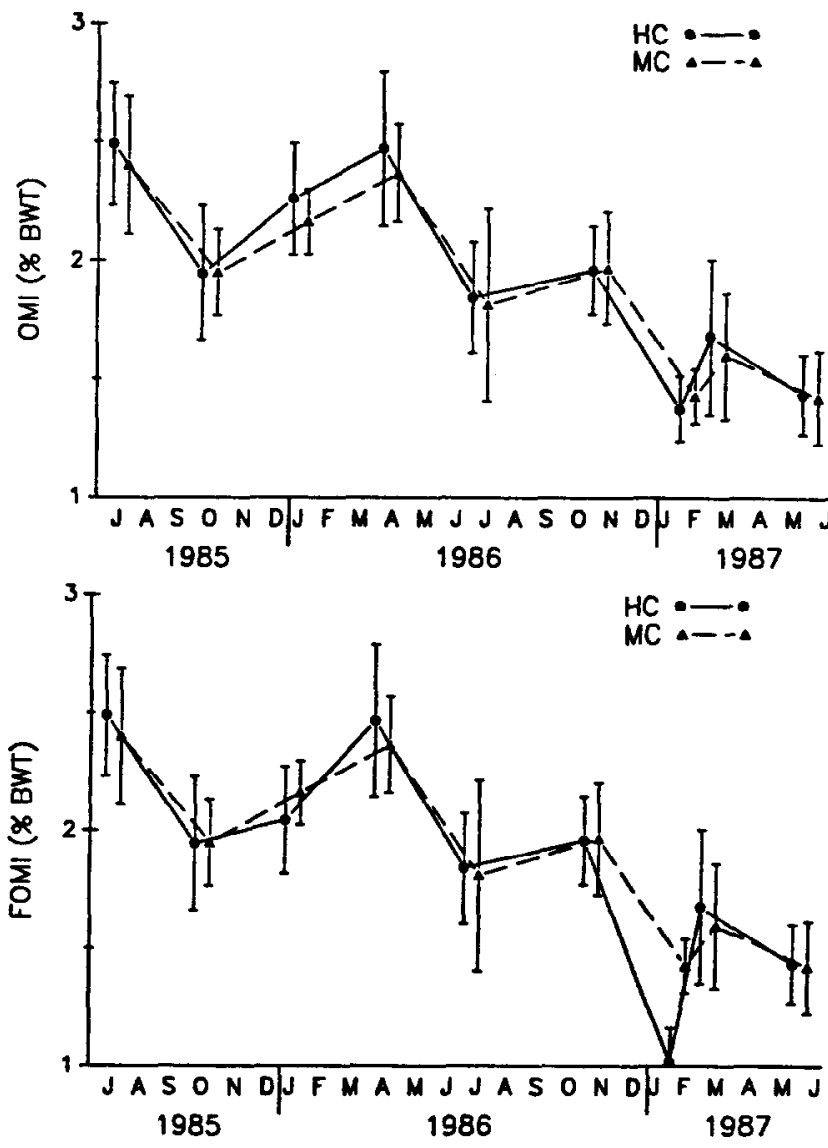

Fig. 4. Seasonal dynamics of organic matter intake (OMI) and forage organic matter intake (FOMI) under long-term heavy $(\bullet)$ and moderate $(\Delta)$ continuous grazing (HC and MC, respectively) during 9 trials from July 1985 to June 1987 . Mean \pm standard deviation.

relative impacts of quantity and quality of forage available of FOMI. There was no significant treatment effect on FOMI although Heitschmidt et al. (1989) showed in a companion study that (1) quantity of available forage was significantly greater in the MC than HC treatment on all dates and (2) quality of forage available was generally greater in the $\mathrm{HC}$ than $\mathrm{MC}$ treatment. Although FOMI for both MC and HC treatments were very sim- 
ilar, a notable exception occurred in February 1987 when FOMI in the MC treatment was significantly greater than in the HC treatment. On this date, estimated grass standing crop in the MC treatment was $1,221 \mathrm{~kg} / \mathrm{ha}$ as compared to $699 \mathrm{~kg} / \mathrm{ha}$ in the $\mathrm{HC}$ treatment. Percentage CP of graminoids averaged 7.8 and $8.5 \%$ in the $\mathrm{MC}$ and $\mathrm{HC}$ treatments, respectively, and percentage IVOMD averaged 43 and $47 \%$, respectively. Apparently quantity rather than quality of available herbage limited FOMI.

The absence of any difference between treatments for FOMI in January 1986, coupled with slightly greater OMI in the HC than MC treatment, indicates supplemental feed OM in the HC treatment was simply replacing forage $\mathrm{OM}$ in the diet. This is in contrast to February 1987 when FOMI was significantly less in the HC than MC treatments and OMI was equal. In this instance, the supplemental $O M$ was substituting for insufficient dietary forage organic matter.

There was an overall trend of decreasing OMI and FOMI from April 1986 through June 1987, which we believe was a result of steer age and body condition. Forage intake levels during the June 1987 trial were much lower than expected in both treatments. They were not significantly higher than those estimated under severe intake restrictions in the February 1987 trial; this can be attributed to tester steers being overly conditioned. Since steers were utilized in the present study, changes in intake among trials can only reflect changes in the quantity and quality of forage available and consumed as modified by the relative body condition of the steers before and during a trial period. Hence, absolute estimates of effects on intake of changes in physiological state, associated with spring calving cows, are not possible.

\section{Discussion}

The results of this study show that 27 years of continuously grazing at moderate and heavy rates of stocking has led to divergent diet selection and forage intake patterns. Under continuous grazing, stocking rate is the primary factor affecting the intensity and frequency of individual plant defoliation (Briske and Stuth 1982, Gammon and Roberts 1978), which in turn affects the competitive ability of plants (Jameson 1963). Hence, there has been a change in the vegetative complex under $\mathrm{HC}$ to a more grazing tolerant shortgrass complex as opposed to a mid-grass complex under MC (Heitschmidt et al. 1989). Assuming greater forage standing crop under $\mathrm{MC}$ facilitated increased expression of forage preference, cattle in $\mathrm{HC}$ treatments were forced to alter diet selection patterns by consuming less Texas wintergrass and more warmseason short- and midgrasses (Fig. 2). However, in the present study, this switch did not alter diet quality in that indices of nutritive value (IVOMD, CP, ADF) were comparable between treatments. This indicates consuming alternative forages had no deleterious effect on nutrient density of the diet in this experiment. Dietary CP and IVOMD values generally fell within the extremes and followed similar seasonal patterns as previously reported by Walker et al. (1989) for this location. Though not estimated, we believe diet quality was maintained under $\mathrm{HC}$ because consumed plant tissue was younger and of greater nutritive value.

Seasonal forage selection patterns closely followed seasonal growth dynamics. This finding is consistent with previous research (Walker et al. 1989, Pfister et al. 1984, Stuth et al. 1987) which has shown seasonal differences in herbage growth dynamics is a major factor influencing botanical composition of cattle diets on rangeland. These tendencies are expected because cattle prefer live over dead material (Arnold and Dudzinski 1978, Hodgson 1982, Sollenberger 1987) and leaf over stem (Chacon and Stobbs 1976, Poppi et al. 1980). If preferred food items chronically or seasonally fall below some threshold, alternative food items will be consumed in an effort to maintain caloric stasis, though these foods are not preferred (Pyke 1984, Senft et al. 1987). General absence of significant treatment effects on OMI and FOMI indicate the lower amounts of forage available in the HC than MC treatments (Heitschmidt et al. 1989) did not normally restrict intake. However, the restriction encountered in the $\mathrm{HC}$ treatment in February 1987 (Fig. 4) shows occasional restrictions do occur. The impact of periodic restrictions of intake on cow/calf production is reflected in the livestock production data from these treatments (Heitschmidt et al. 1989a). Average production is comparable but more variable under HC than MC (Whitson et al. 1982, Heitschmidt et al. 1989a). Forage intake under HC declined, relative to MC, at standing crops $<800 \mathrm{~kg} \mathrm{OM} /$ ha, yet was comparable at standing crops $>900 \mathrm{~kg} \mathrm{OM} / \mathrm{ha}$. This range is below that commonly reported on temperate range and pasture lands of $1,000 \mathrm{~kg} / \mathrm{ha}$ (Hodgson 1977, Allison 1985) but well above the $175 \mathrm{~kg} /$ ha limit found on seeded crested wheatgrass pasture (Handl and Rittenhouse 1972). Though not measured, we would propose intake homeostasis was possible at lower standing crops because the comparatively short $(<50 \mathrm{~cm})$ stature and relatively high leaf:stem ratio of this grass complex does not impose forage density restrictions common to improved pasture conditions (Chacon and Stobbs 1976, Moore et al. 1987, Forbes and Coleman 1987). While switching diet from Texas wintergrass to other warm-season grasses in February 1987 had no deleterious impact on diet quality, this tactic did not facilitate maintenance of FOMI under HC. The lack of sufficient standing crop of a preferred forage limited FOMI as it did in the findings of Stuth et al. (1987) in a SchizachyriumPaspalum savanna.

Seasonal patterns of FOMI and OMI closely followed those of diet CP and IVOMD and reflected the changes in forage quality. Intake increased or decreased as digestibility increased or decreased in a linear manner within a year, which is consistent with the findings of Hodgson (1977) and Freer (1981) that show voluntary forage intake increases linearly over a range of digestibility from 40 to $80 \%$. The overall decline in intake, as percentage of body weight, from October 1985 through June 1987, is an artifact of tester steers maturing and becoming overly conditioned and does not reflect climatic or treatment effects.

The effect of supplemental feeding on OMI and FOMI of freeranging cattle is variable (Rittenhouse et al. 1970, Caton et al. 1988, Kartcher 1980, Judkins et al. 1987) and depends upon the physiologic and nutrient status of the animal, environment, diet quality, forage availability, type of supplement, amount of feed and time of feeding (Adams et al. 1986, Petersen 1987, Horn and McCollum 1987, Galyean 1987, Scales et al. 1974, Lusby et al. 1976). In neither the January 1987 nor February 1987 trials did protein supplementation stimulate FOMI or OMI; thus, it is likely that dietary CP levels $\geq 7 \%$ were sufficient to meet microbial nitrogen requirements (Petersen 1987, Van Soest 1982, Kartcher 1980). Consequently, when adequate forage was available as in January 1986 supplemental feed organic matter simply replaced forage organic matter. Conversely, supplemental feed organic matter substituted for insufficient forage organic matter availability in the February 1987 trial. Hence, based on this experiment, it would appear the supplementation strategy was designed to overcome shortfalls in available forage during winter periods at heavy rates of stocking.

While diet CP content was sufficient to meet nitrogen requirements, it was insufficient to meet spring-calving cow requirements (NRC 1984) during July 1985, January 1986, and July 1986 trials, indicating there is a mid-summer nitrogen depression period $(<9.5 \% \mathrm{CP})$ which may limit animal performance. These findings are in agreement with those of Walker et al. (1989) at this location. We believe the climatic conditions during the present study were conducive to maintaining above-normal levels of forage/diet $\mathrm{CP}$ and IVOMD; thus, these results do not necessarily reflect the low 
nutritive value of forage that may at times occur during winter (Walker et al. 1989, W.E. Pinchak unpublished data) and summer. These findings suggest that future research on the type and amount of supplement fed and its timing is essential to development of cost effective supplementation strategies for the southern mixed-grass prairie.

\section{Literature Cited}

Adams, D.C., T.C. Nelsen, W.L. Reynolds, and B.W. Knapp. 1986. Winter grazing activity and forage intake of range cows in the Northern Great Plains. J. Anim. Sci. 62:1240-1246.

Allison, C.D. 1985. Factors affecting forage intake by range ruminants: a review. J. Range Manage. 38:305-311.

Angell, R.F., J.W. Stuth, and D.L. Drawe. 1986. Diets and liveweight changes of cattle grazing fall burned Gulf cordgrass. J. Range Manage. 39:233-236.

Arnold, G.W., and M.L. Dudzinski. 1978. Ethology of free-ranging domestic animals. Elsevier Scientific Publ. Co., New York.

AOAC. 1980. Official methods of analysis (13th ed.). Assoc. Official Analyt. Chem., Washington, D.C.

Briske, D.D., and J.W. Stuth. 1982. Tiller defoliation in a moderate and heavy grazing regime. J. Range Manage. 35:511-14.

Caton, J.S., A.S. Freeman, and M.L. Galyean. 1988. Influence of protein supplementation on forage intake, in situ forage disappearance, ruminal fermentation and digesta passage rates in steers grazing dormant blue grama rangeland. J. Anim. Sci. 66:2262-2271.

Chacon, E., and T.H. Stobbs. 1976. Influence of progressive defoliation of a grass sward on the eating behavior of cattle. Aust. J. Agr. Res. 27:709-727.

Cook, C.W., K. Taylor, and L.E. Harris. 1962. The effect of range condition and intensity of grazing upon intake and nutritive value of the diet on desert ranges. J. Range Mange. 15:1-6.

Cook, C.W., and L.E. Harris. 1968. Nutritive value of seasonal ranges. Utah Agr. Exp. Sta. Bull. 472.

Ellison, Lincoln. 1960. Influences of grazing on plant succession of rangelands. Bot. Rev. 26:1-78.

Forbes, T.D.A., and S.W. Coleman. 1987. Herbage intake and ingestive behavior of grazing cattle as influenced by variation in sward characteristics. p. 141-152. In: F.P. Horn, J. Hodgson, J.J. Mott, and R.W. Brougham (eds.) Grazing-lands research at the plant-animal interface. Proc. Spec. Sess. XV. Int. Grassland Congr.

Freer, M. 1981. The control of food intake by grazing animals, p. 105-124. In: F.H.W. Morley (ed.) Grazing animals. Elsevier Scientific Publ. Co., New York.

Gammon, D.M., and B.R. Roberts. 1978. Patterns of defoliation during continuous and rotational grazing of the Matopos Sandveld of Rhodesia. III. Frequency of defoliation. Rhod. J. Agr. Res. 16:147-164.

Galyean, M.L. 1987. Factors influencing digesta flow in grazing ruminants. p. 77-90 In: Proc. Grazing Livestock Nutrition Conf. July 23-24, Jackson Hole, Wyo. Univ. Wyoming.

Gurevitch, J., and S.T. Chester, Jr. 1986. Analysis of repeated measures experiments. Ecology 67:251-255.

Handl, W.P., and L.R. Rittenhouse. 1972. Herbage yield and intake of steers. Proc. West. Sec. Amer. Soc. Anima. Sci. 23:197-200.

Hart, R.H. 1978. Stocking rate theory and its application to grazing on rangelands. Proc. 1st Int. Rangeland 1978 Congr.. p. 547-550.

Heitschmidt, R.K., S.L. Dowhower, R.A. Gordon, and D.L. Price. 1985. Response of vegetation to livestock grazing at the Texas Experimental Ranch. Tex. Agr. Exp. Sta. 2M-1-86.

Heitschmidt, R.K., S.L. Dowhower, and J.W. Walker. 1987. 14- vs. 42paddock rotational grazing: Forage quality. J. Range Manage. 40:315-317.

Heitschmidt, R.K., J.R. Conner, S.K. Canon, W.E. Pinchak, J.W. Walker, and S.L. Dowhower, 1989a. Cow/calf production and economic returns from yearlong continuous, deferred rotation and rotational grazing treatments. J. Prod. Agr. 3:92-99.

Heitschmidt, R.K., S.L. Dowhower, W.E. Pinchak, and S.K. Canon. 1989b. Effects of stocking rate on quantity and quality of available forage. J. Range Manage. 42:468-473.

Hodgson, J. 1977. Factors limiting forage intake by the grazing animal. p. 70-75. Proc. Int. Meet. Anim. Prod. Temp. Grassl. Dublin, Ireland, June 1977.
Horn, G.W., and F.T. McCollum. 1987. Energy supplementation of grazing livestock. p. 125-136. In: Proc. Grazing Livestock Nutrition Conf. July 23-24. Jackson Hole, Wyo. Univ. Wyoming.

Jameson, Donald A. 1963. Responses of individual plants to harvesting. Bot. Review 29:532-594.

Judkins, M.B., J.D. Wallace, M.L. Galyean, L.J. Krysl, and E.E. Parker. 1987. Passage rates, rumen fermentation, and weight change in protein supplemented grazing cattle. J. Range Manage. 40:100-104.

Kartchner, R.J. 1980. Effects of protein and energy supplementation of cows grazing native winter forage on intake and digestibility. J. Anim. Sci. 51:432-438.

Lusby, K.S., D.F. Stephens, and Robert Totusek. 1976. Influence of breed and level of winter supplement on forage intake of range cows. J. Anim. Sci. 43:543-548.

Moore, J.E., L.E. Sollenberger, G.E. Morantes, and P.T. Beede. 1987. Canopy Structure of Aeschynome americana-Hemarthira altissima pastures and ingestive behavior of cattle. p. 93-114. In: F.P. Horn, J. Hodgson, J.J. Mott, and R.W. Brougham (eds.) Grazing-lands research at the plant-animal interface. Proc. Special Session, XV Int. Grassl. Congr.

NRC. 1984. Nutrient requirements of beef cattle, sixth edition. Nat. Res. Counc., Nat. Academy Press. Washington, D.C.

Peterson, M.K. 1987. Nitrogen supplementation of grazing livestock. p. 115-122. In: Proc. Grazing Livestock Nutrition Conf. July 23-24. Jackson Hole, Wyo. Univ. Wyoming.

Pfister, J.A., G.B. Donart, R.D. Pieper, J.D. Wallace, and E.E. Parker. 1984. Cattle diets under continuous and four pasture, one-herd grazing systems in south central New Mexico. J. Range Manage. 37:50-54.

Poppi, D.P., D.J. Minson, and J.H. Ternouth. 1980. Studies of cattle and sheep eating leaf and stem fractions of grass. I. The voluntary intake, digestibility and retention time in the reticulo-rumen. Aust. J. Agr. Res. 32:99-108.

Pyke, G.H. 1984. Optimal foraging theory: A critical review. Ann. Rev. Ecol. Syst. 15:523-575.

Rittenhouse, L.R., C.D. Clanton, and C.L. Streeter. 1970. Intake and digestibility of winter range forage by cattle with and without supplementation. J. Anim. Sci. 31:1215-1221.

Scales, G.H., A.H. Denham, C.L. Streeter, and G.M. Ward. 1974. Winter supplementation of beef calves on sandhill range. J. Anim. Sci. 38:442-448

Senft, R.L., M.B. Coughenour, D.W. Bailey, L.R. Rittenhouse, O.E. Sala, and D.M. Swift. 1987. Large herbivore foraging and ecological hierarchies. Bioscience 37:789-799.

Sollenberger, L.E., J.E. Moore, K.H. Quesenberry, and P.T. Beede. 1987. Relationships between canopy botanical composition and diet selection in aeschynomene-limpograss pastures. Agron. J. 79:1049-1054.

Stuth, J.W., J.R. Brown, P.D. Olson, M.R. Araujo, and H.D. Aljoe. 1987. Effects of stocking rate on critical plant-animal interactions in a rotationally grazed Schizachyrium-Paspalum Savanna. p. 115-140. In: F.P. Horn, J. Hodgson, J.J. Mott, R.W. Brougham (eds.) Grazing-lands research at the plant-animal interface, Proc. Spec. Sess. XV Int. Grassl. Congr.

Teeter, R.G., F.N. Owens, and T.L. Mader. 1984. Ytterbium chloride as a marker for particulate matter in the rumen. J. Anim. Sci. 58:465-473.

Tilley, J.M.A., and R.A. Terry. 1963. A two-stage technique for the in vitro digestion of forage crops. J. Brit. Grassl. Soc. 18:104-111.

Van Soest, P.J., R.H. Wine, and L.A. Moore. 1966. Estimation of the true digestibility of forage by the in vitro digestion of cell walls. Proc. 10th Int. Grassl. Congr. 10:438-441.

Van Soest, P.J., and R.H. Wine. 1967. Use of detergents in the analyses of fibrous feeds. IV. The determination of plant cell-wall constituents. $J$. Assoc. Off. Anal. Chem. 50:50-55.

Van Soest, P.J. 1982. The nutritional ecology of the ruminant. O\&B, Corvallis.

Walker, J.W., R.K. Heitschmidt, E.A. de Moraes, M.M. Kothmann, and S.L. Dowhower. 1989. Quality and botanical composition of cattle diets under rotational and continuous grazing treatments. J. Range Manage. 42:239-242.

Whitson, R.E., R.K. Heitschmidt, M.M. Kothmann, and G.K. Lundgren. 1982. The impact of grazing systems on the magnitude and stability of ranch income in the Rolling Plains of Texas. J. Range Manage. 35:526-532. 